\title{
UJI AKTIVITAS ANTIMIKROBA EKSTRAK DAN FRAKSI ALGA Turbinaria ornata (Turner) J.Argadh DARI PERAIRAN DESA TUMBAK, MINAHASA TENGGARA TERHADAP Staphylococcus aureus, Escherichia coli dan Candida albicans
}

\author{
Vaneza Christine Lawani $^{1)}$, Herny E.I Simbala ${ }^{1)}$, Henki Rotinsulu ${ }^{1)}$ \\ ${ }^{1)}$ Program Studi Farmasi FMIPA UNSRAT Manado, 95115
}

\begin{abstract}
Algae are chromista that live in the ocean, some are stranded on the beach, attached to rocks with a kind of root adhesives. Algae produce many compounds, which can be used as antimicrobial and anticancer. This study aims to determine the antimicrobial activity of the extracts and fractions of Turbinaria ornata algae collected from the of Ponteng Island waters, Tumbak, Southeast Minahasa against Staphylococcus aureus, Escherichia coli and Candida albicans. Turbinaria ornata algae were extracted using maceration method with $96 \%$ of ethanol solvent and fractionation using a partition method with $n$-hexane, chloroform and methanol as well as antimicrobial testing using the Kirby Bauer diffusion method. The results of this study indicate that ethanol extract of algae Turbinaria ornata has moderate category of antimicrobial activity in methanol, n-hexane and chloroform fractions with an average inhibition of 7.33 mm against Staphylococcus aureus, Escherichia coli and Candida albicans.
\end{abstract}

Keywords: Antimicrobials, Extraction, Fractionation, Turbinaria ornata

\begin{abstract}
ABSTRAK
Alga merupakan chromista yang hidup lautan ada yang terdampar di pinggir pantai, melekat pada batu-batuan dengan alat pelekat semacam akar. Alga banyak menghasilkan senyawa yang dapat digunakan sebagai antimikroba dan antikanker, Penelitian ini bertujuan untuk mengetahui aktivitas antimikroba ekstrak dan fraksi alga Turbinaria ornata yang dikoleksi dari perairan pulau Ponteng, desa Tumbak, Minahasa Tenggara terhadap Staphylococcus aureus, Escherichia coli dan Candida albicans. Alga Turbinaria ornata diekstraksi menggunakan metode maserasi dengan pelarut etanol $96 \%$ dan fraksinasi menggunakan metode partisi dengan pelarut $\mathrm{n}$-heksan, kloroform dan metanol serta pengujian antimikroba menggunakan metode difusi agar Kirby Bauer. Hasil dari penelitian ini menunjukkan bahwa ekstrak etanol Alga Turbinaria ornata memiliki aktivitas antimikroba kategori sedang pada fraksi metanol, n-heksan dan kloroform dengan daya hambat rata-rata 7,33 $\mathrm{mm}$ terhadap Staphylococcus aureus, Escherichia coli dan Candida albicans.
\end{abstract}

Kata kunci: Antimikroba, Ekstraksi, Fraksinasi, Turbinaria ornata 


\section{PENDAHULUAN}

Alga yang hidup di perairan Indonesia sangat beragam, terdapat sekitar 782 jenis yang terdiri dari 196 jenis hijau, 134 jenis coklat, dan 452 jenis merah. Kelimpahan alga dapat dijadikan peluang yang baik jika diketahui cara memanfaatkannya ke bidang seperti industri pangan dan industri non-pangan (Anggadiredja et al., 2006). Alga coklat menghasilkan alginat (alginofit) dengan penyebaran yang terbanyak di perairan Indonesia adalah spesies dari genus Sargassum dan Turbinaria (Yunizal, 2004). Turbinaria ornata adalah salah satu jenis alga coklat yang menghasilkan alginat (Rasyid, 2000).

Infeksi oleh mikroba patogen terus mengalami peningkatan seiring munculnya kasus mikroba patogen yang resisten terhadap antibiotik, misalnya Staphylococcus aureus, Escherichia coli, Klebsiella sp., dan Morganella sp., banyak ditemukan resisten terhadap antibiotik golongan $\beta$-laktam seperti penisilin (Mardiastuti et al., 2007). Kondisi tersebut memacu pencarian sumber bahan antimikroba baru yang dapat menghambat dan membunuh bakteri-bakteri patogen (Tinambunan et al., 2012).

Aktivitas antimikroba senyawa protein dari alga coklat juga telah diteliti. Arifuddin et al. (2001), melaporkan bahwa fraksi protein $40-60 \%$ dari alga coklat Sargassum echinocarpum J.G Agardh dan Turbinaria decurrens bory efektif menghambat pertumbuhan bakteri Escherichia coli dan Staphylococcus aureus dengan diameter hambat $>14 \mathrm{~mm}$.

Akhir-akhir ini para peneliti bahan alam cenderung untuk menemukan bahan obat dari laut yang dapat digunakan pada berbagai penyakit seperti kanker, peradangan, malaria dan infeksi oleh bakteri dan jamur. Hal ini terjadi karena adanya masalah kesehatan dengan mortalitas yang tinggi di negara-negara berkembang dan perkembangan resistensi mikroorganisme patogen terhadap beberapa obat (Rajasekar et al., 2012)..

\section{METODOLOGI PENELITIAN Bentuk Penelitian}

Penelitian yang dilakukan bersifat eksperimental laboratorium yang menguji aktivitas antimikroba ekstrak dan fraksi alga Turbinaria ornata

\section{Waktu dan Tempat Penelitian}

Penelitian ini dilaksanakan pada bulan Maret 2019 - September 2019 di Laboratorium Penelitian Farmasi Lanjut Program Studi Farmasi Fakultas Matematika dan Ilmu Pengetahuan Alam Universitas Sam Ratulangi Manado.

\section{Alat dan Bahan}

\section{a. Alat}

Alat yang digunakan pada penelitian ini ialah scuba diving (Peralatan Selam), ziplok, gunting, sarung tangan, botol air kemasan $600 \mathrm{~mL}$, pisau, telenan, corong pisah, corong gelas, wadah kaca, erlenmeyer, gelas ukur (Pyrex), gelas kimia (Pyrex), tabung reaksi, rak tabung reaksi, micro tubes, cawan petri, timbangan analitik, vortex (Benchmark), spatula, oven, pinset, batang pengaduk, pembakar spritus, pipet tetes, jarum ose, vial, lemari pendingin, incubator incucell (N-Biotek), laminary air flow (Clean Bench), autoklaf (autoklaf KT-30s), 
mikropipet, jangka sorong, digital caliper, jas laboratorium dan kamera

\section{b. Bahan}

Bahan yang digunakan dalam penelitian ini ialah Alga Turbinaria ornata, Staphylococcus aureus, Escherichia coli, Candida albicans, aquades, etanol, n-heksan, kloroform, metanol, pepton, ekstrak daging (meat extract), natrium klorida, nutrient agar, kloramfenikol (paper disc), kertas label, spidol permanen, kertas saring, kapas, aluminium foil dan tissue.

\section{Prosedur Penelitian}

\section{Ekstraksi}

Pembuatan ekstrak dilakukan dengan metode maserasi yaitu sebanyak 199 gram sampel dimasukkan ke dalam gelas beker lalu direndam dalam pelarut etanol 96\%, sampai sampel terendam semuanya, dikocok-kocok lalu dibiarkan selama 1x24 jam, sampel yang sudah direndam kemudian disaring menggunakan corong dan kertas saring. Menghasilkan filtrat 1 dan debris 1 . Debris 1 direndam kembali dengan etanol $96 \%$ sampai terendam semuanya, debris dikocok-kocok dan dimaserasi selama 1x24 jam. Diulangi cara yang sama sampai diperoleh 3 filtrat dan 3 debris. Filtrat dievaporasi menggunakan oven dengan suhu $40^{\circ} \mathrm{C}$ hingga diperoleh ekstrak kasar alga Turbinaria ornata dan ditimbang dengan timbangan analitik. Ekstrak kasar alga Turbinaria ornata yang dihasilkan dari proses ekstraksi sebanyak 7,9 gram.

\section{Fraksinasi}

Ekstrak kasar alga Turbinaria ornata sebanyak 4,00 gram dimasukkan dalam Erlenmeyer, dilarutkan dengan campuran metanol : air $\left(\mathrm{MeOH}: \mathrm{H}_{2} \mathrm{O}\right)$ (80:20) sebanyak $100 \mathrm{~mL}$. Setelah sampel larut, dimasukkan dalam corong pisah lalu ditambahkan pelarut n-heksan dengan jumlah yang sama, setelah itu dikocok berulangkali sampai homogen. Dibiarkan sampai terbentuk dua lapisan metanol : air $\left(\mathrm{MeOH}: \mathrm{H}_{2} \mathrm{O}\right)$ dan n-heksan. Masingmasing lapisan ditampung dalam wadah yang berbeda. Lapisan n-heksan dievaporasi menggunakan oven hingga kering, lalu ditimbang dengan timbangan analitik dan diperoleh fraksi n-heksan 0,0072 gram. Lapisan $\mathrm{MeOH}: \mathrm{H}_{2} \mathrm{O}$ ditambahkan akuades sebanyak $100 \mathrm{~mL}$ dipartisi dengan pelarut kloroform dengan perbandingan $1: 1 \mathrm{v} / \mathrm{v}$ dalam corong pisah, lalu dikocok berulangkali sampai homogen. Dibiarkan sampai terbentuk dua lapisan yaitu lapisan $\mathrm{MeOH}$ dan kloroform. Masing - masing lapisan ditampung dalam wadah yang berbeda. Lapisan kloroform dievaporasi menggunakan oven hingga kering lalu ditimbang dan diperoleh fraksi kloroform 0,0303 g. Lapisan $\mathrm{MeOH}$ yang ditampung pada wadah yang lain dievaporasi menggunakan oven hingga kering lalu ditimbang berat sampel, dan diperoleh fraksi $\mathrm{MeOH}$ 0,1869 g.

\section{Sterilisasi Alat}

Alat-alat yang digunakan dalam penelitian uji daya hambat ini disterilkan terlebih dahulu. Alat - alat gelas disterilkan menggunakan autoklaf pada suhu $121^{\circ} \mathrm{C}$ selama 15 menit. 


\section{Pembuatan Media Cair B1}

Ditimbang Pepton 0,5 g, ekstrak daging $0,3 \mathrm{~g}$ (meat extract), Natrium klorida 0,3 g dilarutkan dalam akuades sebanyak $100 \mathrm{~mL}$ menggunakan Erlenmeyer, dikocok sampai homogen. Media yang telah homogen kemudian disterilkan dengan menggunakan autoklaf pada suhu $121^{\circ} \mathrm{C}$ selama 15 menit. Dipipet $1 \mathrm{~mL}$ media cair B1, kemudian masukkan dalam tabung reaksi dan tutup dengan aluminium foil. Media cair B1 siap digunakan sebagai media kultur mikroba (Ortez, 2005).

\section{Kultur Mikroba}

Masing - masing mikroba yang sudah dikultur (Escherichia coli, Staphylococcus aureus dan Candida albicans) ditambahkan media cair B1 yang disiapkan sebelumnya sebanyak $100 \mu \mathrm{L}$ kedalam tabung reaksi yang berbeda beda. Masing - masing tabung reaksi ditutup dengan aluminium foil dan dimasukkan ke dalam inkubator selama $1 \times 24$ jam dengan suhu $37^{\circ} \mathrm{C}$ (Ortez, 2005).

\section{Pembuatan Kontrol (Positif dan Negatif)} Kontrol postif yang digunakan yaitu Kloramfenikol Paper Disc dan Kontrol negatif yang digunakan dalam penelitian ini yaitu menggunakan metanol, dengan cara membuat larutan stok metanol dengan mengambil sebanyak $200 \mu \mathrm{l}$ metanol kemudian ditotolkan pada paper disc.

\section{Pembuatan Larutan Uji}

Sebanyak 1 mg ekstrak kasar alga Turbinaria ornata dilarutkan dalam 200 $\mu \mathrm{L}$ metanol sehingga menghasilkan konsentrasi larutan uji sebesar $250 \mu \mathrm{g} / 50$ $\mu \mathrm{L}$ (Ortez, 2005). Perlakuan yang sama dilakuakan untuk fraksi metanol, fraksi kloroform dan fraksi n-heksan.

\section{Pembuatan Media Agar B1}

Pepton 0,5 g, ekstrak daging (meat extract) 0,3 g, natrium klorida 0,3 g, nutrient agar 1,5 g dan dilarutkan dalam akuades sebanyak $100 \mathrm{~mL}$ menggunakan Erlenmeyer, dikocok sampai homogen. Media yang telah homogen kemudian disterilkan dengan menggunakan autoklaf pada suhu $121^{\circ} \mathrm{C}$ selama 15 menit. Media agar B1 siap digunakan untuk uji aktivitas antimikroba (Ortez, 2005).

\section{Pengujian Aktivitas Antimikroba}

Metode yang digunakan yaitu Metode Difusi (Disc Diffusion Kirby and Bauer). Pengujian aktivitas antimikroba ini cakram (paper disc) yang digunakan berukuran $6 \mathrm{~mm}$ dengan daya serap $50 \mu \mathrm{L}$ tiap cakram. Diinokulasi suspensi mikroba dalam media dan dihomogenkan. Media yang sudah diinokulasi mikroba dituangkan dalam cawan petri sampai media memadat, kemudian cawan petri diberi label Sampel yang telah ditentukan kosentrasinya $(250 \mu \mathrm{g} / 50 \mu \mathrm{L})$ ditotolkan pada masing-masing cakram dengan menggunakan mikropipet, kemudian diletakkan kertas cakram yang sudah ditotol ke dalam cawan petri dan diinkubasi 1 x 24 jam (Ortez, 2005).

\section{Pengamatan dan Pengukuran Zona Hambat}

Pengamatan dilakukan setelah 1x24 jam masa inkubasi. Daerah pada sekitaran cakram menunjukkan kepekaan mikroba terhadap antibiotik atau bahan antimikroba yang digunakan sebagai bahan uji yang 
dinyatakan dengan diameter zona hambat atau zona bening. Diameter zona hambat diukur dalam satuan millimeter (mm) menggunakan Digital Caliper dengan cara diukur diameter total zona bening cakram. Kemudian diameter zona hambat tersebut dikategorikan kekuatan daya anti bakterinya berdasarkan penggolongan Davis dan Stout (1971). Klasifikasi zona Hambat menurut Davis dan Stout (1971) dapat lihat pada Tabel 1.

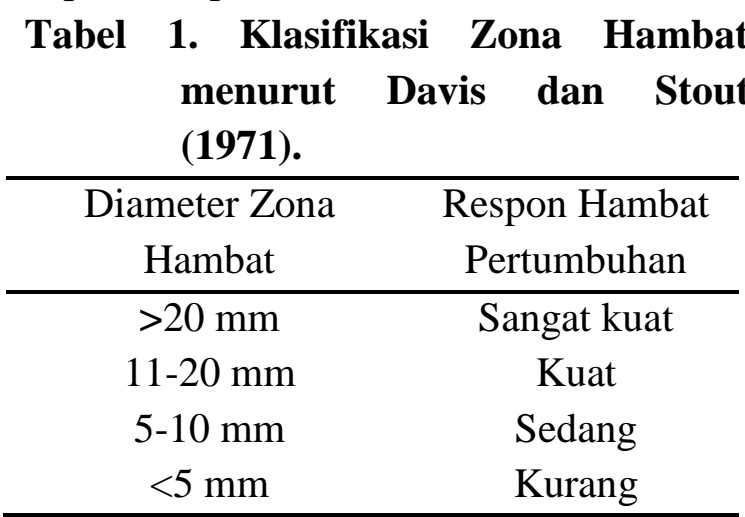

Teknik Pengolahan dan Analisis Data

Teknik pengolahan data dilakukan dengan model penyajian dalam bentuk tabel dan gambar, grafik dan dianalisis secara deskriptif. Aktivitas antibakteri diukur menggunakan penggaris skala millimeter berdasarkan zona hambat yang terbentuk dan dikurangi dengan diameter kertas cakram, kemudian di rata-ratakan dari tiga kali pengujian.

\section{HASIL DAN PEMBAHASAN}

\section{a. Hasil}

Keterangan :

EKE : Ekstrak Kasar Etanol

FK : Fraksi Kloroform

FM : Fraksi Metanol

FN : Fraksi n-Heksan
Tabel 2. Hasil pengukuran diameter zona hambat ekstrak dan fraksi Alga (Turbinaria ornata) terhadap $\quad S$. aureus, $E$. coli dan $C$. albicans

\begin{tabular}{|c|c|c|c|c|c|c|c|}
\hline Mikroba & Ulangan & EE & $\mathrm{FM}$ & $\mathrm{FH}$ & FK & $\begin{array}{c}\text { Kontrol } \\
(t)\end{array}$ & $\begin{array}{c}\text { Kontrol } \\
(-)\end{array}$ \\
\hline \multirow{5}{*}{$\begin{array}{l}\text { Escheric } \\
\text { hia coli }\end{array}$} & 1 & 7,00 & 8,00 & 7,00 & 7,00 & 24,00 & 0,00 \\
\hline & \|I & 7,00 & 7,00 & 7,00 & 7,00 & & \\
\hline & III & 7,00 & 7,00 & 7,00 & 7,00 & & \\
\hline & Jumlah & 21,00 & 22,00 & 21,00 & 21,00 & & \\
\hline & Ratarata & 7,00 & 7,33 & 7,00 & 7,00 & & \\
\hline \multirow{5}{*}{$\begin{array}{l}\text { Staphyio } \\
\text { coccus } \\
\text { auereus }\end{array}$} & I & 7,00 & 8,00 & 7,00 & 7,00 & 23,00 & 0,00 \\
\hline & II & 7,00 & 7,00 & 7,00 & 7,00 & & \\
\hline & III & 7,00 & 7,00 & 7,00 & 7,00 & & \\
\hline & Jumlah & 21,00 & 22,00 & 21,00 & 21,00 & & \\
\hline & Rata-rata & 7,00 & 7,33 & 7,00 & 7,00 & & \\
\hline \multirow{5}{*}{$\begin{array}{l}\text { Candida } \\
\text { ailbicans }\end{array}$} & 1 & 7,00 & 8,00 & 7,00 & 7,00 & 20,00 & 0,00 \\
\hline & II & 7,00 & 7,00 & 7,00 & 7,00 & & \\
\hline & III & 7,00 & 7,00 & 7,00 & 7,00 & & \\
\hline & Jumlah & 21,00 & 22,00 & 21,00 & 21,00 & & \\
\hline & Rata-rata & 7,00 & 7,33 & 7,00 & 7,00 & & \\
\hline
\end{tabular}

\section{b. Pembahasan}

Ekstraksi merupakan proses penarikan komponen - komponen yang diinginkan dari sampel (Khopkar, 2003). Sampel alga Turbinaria ornata dipotong kecil - kecil bertujuan untuk memudahkan senyawa aktif yang terkandung dalam alga Turbinaria ornata untuk tertarik kedalam pelarut dan untuk memperluas ukuran permukaan sampel, karena semakin kecil ukuran sampel maka luas permukaan sampel akan meningkatkan laju ektraksi, yang berarti semakin banyak senyawa yang tertarik ke dalam pelarut (Ghozali, 1996). Sampel alga Turbinaria ornata selanjutnya diekstraksi dengan metode maserasi. Proses maserasi dilakukan dengan cara merendam sampel alga Turbinaria ornata selama $1 \times 24$ jam sebanyak 3 kali dengan menggunakan pelarut etanol 96\%. Menurut Dean (2009), pemilihan metode maserasi karena metode maserasi dapat mengekstraksi senyawa aktif dengan baik melalui perendaman. Cairan penyari akan menembus dinding sel dan masuk ke dalam rongga sel yang 
mengandung zat aktif yang akan larut, karena adanya perbedaan kosentrasi larutan zat aktif di dalam sel dan di luar sel maka larutan terpekat didesak keluar. Proses ini berulang sehingga terjadi keseimbangan konsentrasi antara larutan di dalam dan diluar sel (Dea, et al., 2014). Etanol adalah pelarut terbaik yang bersifat polar untuk ekstraksi senyawa fenolik pada hampir semua spesies rumput laut jika dibandingkan dengan dengan pelarut lainnya (Hidayah et al, 2016). Hasil ekstrak Alga Turbinaria ornata diuapkan menggunakan oven dengan suhu $37^{\circ} \mathrm{C}$, Menurut Vogel (1978), penguapan ekstrak ini bertujuan untuk menghilangkan pelarut dan air yang tersisa dalam ekstrak.

Hasil ekstrak kasar Alga Turbinaria ornata yang diperoleh di lanjutkan ke tahap fraksinasi. Fraksinasi merupakan proses pemisahan antara zat cair dengan zat cair yang dilakukan berdasarkan tingkat kepolarannya. Senyawa yang memiliki sifat non polar akan larut dalam pelarut non polar, senyawa yang memiliki sifat semi polar akan larut dalam pelarut semi polar, dan senyawa yang memiliki sifat polar akan larut dalam palrut polar (Harborne, 1987). Tujuan penggunaan pelarut n-heksan, kloroform dan metanol adalah untuk memisahkan senyawa - senyawa yang terdapat pada ekstrak Turbinaria ornata sesuai dengan sifat kepolarannya, sehingga komponennya lebih sederhana. Dimana pelarut n-heksan digunakan untuk menarik senyawa yang bersifat non polar, pelarut kloroform digunakan untuk menarik senyawa yang bersifat semi polar sedangkan pelarut metanol digunakan untuk menarik senyawa yang bersifat polar (Defran, et al., 2015). Berdasarkan tingkat kepolaran akan terbentuk dua lapisan, pelarut dengan massa jenis lebih tinggi berada di lapisan bawah sedangkan pelarut dengan massa jenis lebih kecil berada di lapisan atas. Fraksi yang diperoleh diuapkan menggunakan oven dan digunakan untuk uji aktivitas antimikroba. Sampel ekstrak etanol yang dihasilkan berwarna coklat dengan massa jenis yang diperoleh yaitu 7,9 gr dari hasil maserasi sebanyak 199 gr dengan nilai rendemen yaitu $0,039 \%$. Kemudian ekstrak etanol sebanyak 4,00 g difraksinasi menggunakan pelarut n-heksan, kloroform dan metanol. Ekstrak kasar etanol alga Turbinaria ornata di fraksinasi dengan metanol air kemudian dipartisi dengan pelarut $\mathrm{n}$ heksan menghasilkan dua lapisan, yaitu lapisan $\mathrm{n}$ - heksan dan lapisan metanol. Warna yang dihasilkan dari filtrat fraksi $\mathrm{n}$ - heksan yaitu coklat terang dengan massa ekstrak yang diperoleh 0,00272 g dari massa awal sampel 4,00 g dengan nilai rendemen yang diperoleh $1,088 \%$. Lapisan metanol dipartisi kembali dengan pelarut kloroform hingga menghasilkan dua lapisan yaitu lapisan kloroform dan lapisan metanol. Warna dari filtrat kloroform yaitu hitam dengan massa ekstrak 0,0303 g dari massa awal sampel 4,00 g dengan nilai rendemen $12,12 \%$. Dan untuk lapisan metanol, filtrat yang dihasilkan berwarna kuning kecoklatan dengan massa ekstrak yang diperoleh yaitu $0,1869 \mathrm{~g}$ dari massa awal sampel 4,00 g dengan nilai rendemen $74,76 \%$ Nilai rendemen yang dihasilkan berbeda hal ini karena besarnya rendemen ekstrak dipengaruhi oleh sifat kepolaran dari pelarut, suhu, waktu ekstraksi serta tingkat kepolaran dari jumlah bahan yang diekstrak yang memiliki polaritas yang sama (Yim et al, 2009 ; Gazali, et al, 
2018). Hasil menunjukkan bahwa rendemen yang dihasilkan fraksi etanol lebih tinggi yaitu $1660 \%$ yang berarti pelarut etanol mampu mengekstrak lebih banyak senyawa - senyawa aktif dari sampel. Hal ini menunjukan adanya aktivitas antimikroba yang terbentuk, yang berarti ada kandungan senyawa antimikroba yang bersifat polar dan non polar pada sampel uji Alga Turbinaria ornata dan menunjukkan bahwa komponen senyawa polar Turbinaria ornata lebih banyak. Etanol merupakan pelarut yang memiliki sifat polar (Harborne, 1987).

Uji aktivitas antimikroba dari alga Turbinaria ornata terhadap bakteri Escherichia coli mewakili bakteri Gram negatif, bakteri Staphylococcus aureus mewakili bakteri Gram positif dan Candida albicans yang mewakili Jamur menggunakan Metode difusi agar (difusi Kirby-Bauer yang telah dimodifikasi). Pertumbuhan bakteri setelah inkubasi selama 1x24 jam terlihat menjauhi cakram, hal ini berarti terjadi pembentukan zona hambat di sekitar cakram yang telah ditotolkan sampel uji Alga Turbinaria ornata dan pada cakram antibiotik Kloramfenikol. Pada cakram kontrol negatif tidak terlihat adanya zona hambat. Zona hambat yang terbentuk diukur diameternya dengan menggunakan jangka sorong dengan satuan milimeter (mm). Pengukuran dilakukan dengan cara mengukur diameter dari ujung yang satu ke ujung yang lain melalui tengah-tengah cakram. Aktivitas yang terbentuk terlihat dari adanya zona hambat di sekitaran cakram dengan ukuran cakram (paper disc) $6 \mathrm{~mm}$, membuktikan bahwa ekstrak dan fraksi alga Turbinaria ornata yang diujikan menunjukkan kepekaan terhadap masing - masing mikroba dan antibiotik yang digunakan sebagai kontrol positif. Berdasarkan hasil pengamatan yang dilakukan terhadap mikroba Staphylococcus aureus, Escherichia coli dan Candida albicans masing-masing sebanyak tiga kali pengulangan memperlihatkan adanya zona hambat yang terbentuk disekitar disk/cakram. Diameter zona hambat ekstrak dan fraksi alga Turbinaria ornata terhadap Escherichia coli yang paling besar dihasilkan oleh fraksi metanol yaitu sebesar 22,00 mm dengan nilai rata-rata $7,33 \mathrm{~mm}$. Diameter zona hambat ekstrak dan fraksi alga Turbinaria ornata terhadap Staphylococcus aureus yang paling besar dihasilkan oleh fraksi metanol yaitu sebesar 22,00 $\mathrm{mm}$ dengan nilai rata-rata 7,33 mm. Diameter zona hambat ekstrak dan fraksi alga Turbinaria ornata terhadap jamur Candida albicans yang paling besar dihasilkan oleh fraksi Metanol 22,00 mm dengan nilai rata-rata $7,33 \mathrm{~mm}$. Hasil pengukuran diameter zona hambat dapat dilihat pada Tabel 3.

Tabel 3. Rendemen ekstrak dan fraksi Turbinaria ornate

\begin{tabular}{|c|c|c|c|}
\hline No. & Sampel & $\begin{array}{c}\text { Randemen } \\
(\%)\end{array}$ & $\begin{array}{c}\text { Warna } \\
\text { Sampel }\end{array}$ \\
\hline 1. & EKE & 1600 & Coklat \\
\hline 2. & $\mathrm{FN}$ & 1,088 & $\begin{array}{l}\text { Coklat } \\
\text { Terano }\end{array}$ \\
\hline 3. & $\mathrm{FK}$ & 12,12 & Hitam \\
\hline 4. & FM & 74,76 & $\begin{array}{c}\text { Kuning } \\
\text { kecoklatan }\end{array}$ \\
\hline
\end{tabular}

Berdasarkan hasil yang diperoleh menyatakan bahwa ekstrak dan fraksi Turbinaria ornata memiliki diameter zona hambat sedang sebagai antimikroba, hasil 
pengukuran diameter zona hambat digolongkan berdasarkan klasifikasi zona hambat menurut Davis dan Stout yang dapat dilihat pada Tabel 1, yang membuktikan bahwa ekstrak dan fraksi alga Turbinaria ornata yang diujikan menunjukkan kepekaan terhadap masing masing mikroba dan antibiotik yang digunakan sebagai kontrol positif. Kontrol positif memperlihatkan aktivitas antimikroba yang paling besar terhadap Staphylococcus aureus, Escherichia coli dan Candida albicans. Kontrol positif yang memiliki diameter daya hambat lebih besar yaitu 24,00 $\mathrm{mm}$ pada Escherichia coli, sedangkan pada Staphylococcus aureus 23,00 $\mathrm{mm}$ dan pada Candida albicans $20,00 \mathrm{~mm}$. Sedangkan pada kontrol negatif tidak menunjukan terbentuknya zona hambat. Hal tersebut menandakan bahwa tidak ada pengaruh kontrol negatif terhadap antimikroba yang diuji. Kontrol negatif yang digunakan yaitu metanol. Aktivitas antimikroba terbentuk disekitar disk/cakram dipengaruhi oleh aktivitas senyawa yang terkandung dalam ekstrak dan fraksi alga Turbinaria ornata. Semakin besar zona hambat yang terbentuk maka semakin besar daya hambat sampel alga Turbinaria ornata terhadap pertumbuhan mikroba.

\section{KESIMPULAN}

Hasil penelitian menunjukkan
bahwa adanya aktivitas antimikroba
ekstrak kasar dan fraksi alga coklat
Turbinaria ornata yang mampu
menghambat pertumbuhan mikroba
Staphylococcus aureus dengan daya
hambat fraksi metanol sebesar 7,33 mm,
Escherichia coli dengan daya hambat
terbesar fraksi metanol $7,33 \mathrm{~mm}$ dan

Candida albicans dengan daya hambat terbesar fraksi metanol 7,33 $\mathrm{mm}$. Dimana perolehan nilai rata-rata dari masingmasing ekstrak dan fraksi uji aktivitas antimkroba termasuk pada kategori sedang.

\section{SARAN}

Perlu dilakukan penelitian lebih lanjut terhadap sampel alga coklat Turbinaria ornata dari lokasi pengambilan sampel yang berbeda agar dapat mengetahui adanya pengaruh kondisi lingkungan tempat alga Turbinaria ornata tumbuh terhadap aktivitas antimikroba. Selain itu perlu dikembangkan dengan dilakukannya uji aktivitas antioksidan untuk mengetahui fungsi dari senyawa yang terkandung dalam sampel alga coklat Turbinaria ornata sebagai antioksidan.

\section{DAFTAR PUSTAKA}

Anggadiredja, J. T., A. Zatnika, H. Purwoto, dan S. Istini, 2006. Rumput Laut Pembudidayaan, Pengolahan dan Pemasaran Komoditas Perikanan Potensial, Jakarta.

Arifuddin, Patong, R., dan Ahmad, A., 2001, Penelusuran Protein Bioaktif dalam Makro Alga sebagai Bahan Antibakteri dan Antijamur, Marina Chimica Acta. 2 (2):11-18.

Davis, W.W., and Stout, T.R. 1971. Disc Plate Methods of Microbiological Antibiotic Assay. Journal Microbiology. 22(4): 659-665.

Dea, A.P, Sura M. Ginting dan Sumpono, 2014. Pengaruh metode ekstraksi dan konsentrasi terhadap aktivitas Jahe merah (zingiber officinale 
var.rubrum) sebagai antibakteri escherichia coli. Jurnal Kimia. 1(1):14

Dean, J, 2009. Extraction Techniques In Analytical Science. John Wiley And Sons LTD, pp. London. 4346.

Defran M.P , Kiki M. Y, dan Reza A.K. 2015. Identifikasi senyawa Antioksidan dalam Rumput Laut Sargassum duplicatum J.G Argadh dari pantai ujung genteng. Jurnal Kesehatan dan farmasi. FMIPA UNSIBA, Bandung.

Gazali, M. Nurjanah, Neviaty P.Z. 2018. Eksplorasi senyawa bioaktif alga cokelat Sargassum sp.Agardh sebagai antioksidan dari pesisir barat Aceh.. Journal IPB: 21(1).

Harborne, J.B. 1987. Metode Fitokimia Penuntun Cara Modern Menganalisis Tumbuhan. Penerbit ITB, Bandung..

Hidayah N, Hisan AK, Solikin A, Irawati, Mustikaningtyas D. 2016. Uji efektivitas ekstrak Sargassum muticum sebagai alternative obat bisul akibat aktivitas Staphylococcus aureus. Journal of Creativity Students. 1(1): 1-9

Mardiastuti, H. W., Karuniawati, A., Kiranasari, A., Ikaningsih, dan Kadarsih, R. 2007. Emerging Resistance Pathogen: Situasi Terkini di Asia, Eropa, Amerika Serikat, Timur Tengah dan Indonesia, Departemen Mikrobiologi. Fakultas
Kedokteran, Universitas Indonesia. 57(3):75-79.

Ortez, J.H. 2005. Disk Diffusion Testing in Manual of Antimicrobial Susceptibility Testing. Marie B. Coyle (Coord.Ed). American Society for Microbiology.

Rajasekar, T., Balaji, S., Kumaran, S., Deivasigamani, $\quad$ B., Pugzhavendhan, S.R. 2012. Isolation and Characterization of Marine Fungal Metabolites against Clinical Pathogens. Asian Pacific Journal of Tropical Disease. Elsevier. 387-S392.

Rasyid, A. 2000. Ekstraksi Natrium alginat dari Turbinaria decurrens asal perairan Pulau Otangala (Sulawesi Utara). Prosiding Seminar Riptek Kelautan Nasional 2: 1-3.

Tinambunan, H., Melki, dan Isnaini, 2012, Efektifitas Ekstrak Bakteri yang Berasosiasi dengan Spons dan Karang Lunak sebagai Antibakteri dari Perairan Pulau Tegal Lampung, Maspari Journal, 4 (2), 225-230.

Vogel, A.I. 1978. Kimia AnalisaKuantitatif Anorganik. Diterjemahkan Pudjaatmaka. EGC, Jakarta.

Yim H.S, Chye FY, Ho SK, Ho CW. 2009. Phenolic profiles of selected edible wild mushrooms as affected by extraction solvent, time and temperature. Assian journal of Food and Agro Industry. 2(3):392401. 
PHARMACON- PROGRAM STUDI FARMASI, FMIPA, UNIVERSITAS SAM RATULANGI,

Volume 8 Nomor 4 November 2019

Yunizal. 2004. Teknologi Pengolahan

Alginat. Pusat Riset Pengolahan

Produk danSosial Ekonomi

Kelautan dan Perikanan, Badan
Riset Kelautan danPerikanan,

Departemen Kelautan dan

Perikanan, Jakarta. 